\title{
RANCANG BANGUN APLIKASI DIAGNOSA PENYAKIT UMUM BERBASIS ANDROID PADA KLINIK CITRA RAYA MEDIKA
}

\author{
Yanuardi ${ }^{1}$ \\ Teknik Informatika, Fakultas Teknik \\ Universitas Muhammadiyah Tangerang \\ Jl. Perintis Kemerdekaan I Babakan No.33, Cikokol, \\ Kec. Tangerang, Kota Tangerang, Banten 15118 \\ Email : yanuardi99@gmail.com
}

\begin{abstract}
ABSTRAK
Sebagian besar penyakit umum yang terjadi di masyarakat sering dianggap remeh dan apabila penyakit ini tidak segera ditangani, maka akan menjadi lebih parah dan serius penanganannya. Keterbatasan pengetahuan dan kurangnya informasi tentang penyakit serta pola pikir kebanyakan orang yang masih awam tentang kesehatan. Oleh karena itu, dirasa sangat diperlukan adanya aplikasi yang dapat memberikan informasi kepada dokter atau petugas kesehatan akan adanya kemungkinan penyakit pada tubuh, sehingga dapat ditindak lanjuti lebih dini. Aplikasi ini menggunakan teknologi aplikasi berbasis Android, dengan memanfaatkan teknologi mobile devices dalam aplikasi diagnosa penyakit umum ini maka pasien dan dokter dapat terbantu. Aplikasi sistem pakar ini menggunakan metode inferensi forward chaining.Dengan hanya memasukkan gejala yang diderita dan user dapat segera tahu jenis penyakit umum yang kemungkinan diderita, sehingga kecepatan dan keefektifan dalam pelayanan dan penanganan terhadap penyakit tersebut dapat segera dilakukan. Dengan dibuatnya suatu aplikasi sistem pakar diagnosa penyakit umum yang berbasis mobile teknologi akan mudah digunakan oleh dokter atau petugas kesehatan.
\end{abstract}

Kata Kunci : sistem pakar, penyakit umum, android, inferensi forward chaining

\section{Pendahuluan}

\subsection{Latar Belakang}

Suatu gejala penyakit merupakan awal dari sebuah penyakit yang dapat mengancam kesehatan seseorang, namun pada kenyataannya gejala penyakit tersebut masih dianggap sepele oleh masyarakat umum. Keterbatasan pengetahuan dan kurangnya informasi tentang penyakit merupakan salah satu alasan gejala penyakit tidak ditanggapi secara serius oleh setiap orang. Banyak yang berpikiran bahwa gejala-gejala yang diderita biasanya hanya gejala penyakit ringan saja dan akan sembuh dengan sendirinya, sehingga tidak terlalu dianggap penting.

Penyakit umum biasanya disebabkan karena pola hidup yang tidak sehat, walaupun penyakit yang sering terjadi pada umumnya tergolong ringan dan berdampak biasa pada tubuh seseorang. Namun, jika penyakit umum baru memasuki gejala-gejala awal atau belum begitu parah, masih ada peluang untuk disembuhkan sangat besar. Masalahnya pada sebagian besar, penderita baru melakukan pemeriksaan ke dokter jika penyakit tersebut sudah memasuki gejala yang lebih parah.
Dengan semakin berkembangnya ilmu pengetahuan dan teknologi komunikasi saat ini, proses untuk mengetahui gejala dan resiko pada penyakit yang biasa dialami oleh masyarakat umum dapat diketahui dengan cepat. Oleh karena itu, sangat diperlukan adanya sebuah aplikasi berbasis android yang dapat membantu dan memberikan informasi kepada seseorang untuk melakukan identifikasi secara dini melalui pengolahan gejala pada perangkat mobile. Sehingga, penanganan lebih lanjut terhadap penyakit dapat segera dilakukan. Selain itu, tak dapat dipungkiri penggunaan aplikasi ini pada kondisi tertentu yaitu untuk mengetahui gejala-gejala awal pada tubuh, dinilai lebih efisien waktu dan menghemat biaya jika dibandingkan menggunakan tenaga medis secara langsung.

Aplikasi yang dibutuhkan tersebut berupa sistem pakar yang bekerja seperti seorang pakar (dokter) dalam mengambil sebuah kesimpulan atau keputusan berdasarkan kondisi tertentu. Sistem pakar dikembangkan dalam berbagai bidang, termasuk dalam bidang medis. Sehingga dalam hal ini sebuah aplikasi sistem pakar berbasis android mampu 
membantu dokter atau perawat dalam mengetahui gejala-gejala awal pada suatu penyakit.

\subsection{Permasalahan}

\section{a. Identifikasi Masalah}

Berdasarkan latar belakang yang telah dijelaskan di atas, maka dapat diidentifikasi masalah yaitu :

1) Keterbatasan pengetahuan dan kurangnya informasi tentang penyakit umum

2) Kadang dimungkinkan terjadi kesalahan dalam mendiagnosis suatu gangguan kesehatan yang dilakukan oleh seorang dokter atau petugas kesehatan. Karena pada dasarnya hampir semua jenis penyakit mempunyai gejala awal yang sama sehingga kurang tepat dalam menentukan keputusan untuk penanganan terhadap penyakit tersebut.

\section{b. Rumusan Masalah}

Bagaimana merancang suatu aplikasi sistem pakar untuk mendiagnosa penyakit umum pada pasien sehingga pengguna dalam hal ini dokter atau petugas kesehatan dapat mengambil keputusan untuk memberikan penanganan yang tepat dan benar?

\section{c. Batasan Masalah}

Agar permasalahan yang ditinjau sesuai dengan tujuan yang ingin dicapai maka perlu membatasi permasalahan yang ada meliputi :

1. Dalam pembuatan aplikasi sistem pakar ini hanya membahas penyakit umum yang sering dialami oleh masyarakat, diantaranya yaitu tifus, radang tenggorokan (faringitis), infeksi saluran pernafasan atas (ISPA), diare, radang lambung atau maag (gastritis), infeksi saluran kemih (sakit kencing), dan vertigo.

2. Aplikasi sistem pakar ini menggunakan metode inferensi forward chaining serta aplikasi yang dibuat merupakan aplikasi berbasis android.

3. Aplikasi ini hanya untuk penanganan awal dan bukan untuk menggantikan posisi dokter.

4. Aplikasi ini bersifat edukatif, bukan solutif.

\section{Landasan Teori}

\subsection{Sistem Pakar}

Menurut Husda dan Wangdra (2016) Pakar adalah "orang yang memiliki pengetahuan, penilaian, pengalaman, metode khusus, serta kemampuan untuk menerapkan bakat ini dalam memberi nasihat dan memecahkan masalah". Pakar biasa memiliki beberapa konsep umum. Pertama, harus mampu memecahkan persoalan dan mencapai tingkat performa yang secara signifikan lebih baik dari orang kebanyakan. Kedua, pakar relatif. Pakar pada satu waktu atau satu wilayah mungkin tidak menjadi pakar di waktu atau wilayah lain. Misalnya, mahasiswa kedokteran mungkin disebut pakar dalam penyakit dibanding petugas administrasi, tetapi bukan pakar di rumah sakit terkemuka.

Bentuk umum sistem pakar adalah suatu program yang dibuat berdasarkan suatu set aturan yang menganalisis informasi (biasanya diberikan oleh pengguna suatu sistem) mengenai suatu kelas masalah spesifik serta analisis matematis dari masalah tersebut. Tergantung dari desainnya, sistem pakar juga mampu merekomendasikan suatu rangkaian tindakan pengguna untuk dapat menerapkan koreksi.

Secara umum, sistem pakar adalah sistem yang berusaha mengadopsi pengetahuan manusia ke komputer yang dirancang untuk memodelkan kemampuan menyelesaikan masalah seperti layaknya seorang pakar. Dengan sistem pakar ini, orang awam pun dapat menyelesaikan masalahnya atau hanya sekedar mencari suatu informasi berkualitas yang sebenarnya hanya dapat diperoleh dengan bantuan para ahli di bidangnya. Sistem pakar ini juga akan dapat membantu aktivitas para pakar sebagai asisten yang berpengalaman dan mempunyai pengetahuan yang dibutuhkan. Dalam penyusunannya, sistem pakar mengkombinasikan kaidahkaidah penarikan kesimpulan (inference rules) dengan basis pengetahuan tertentu yang diberikan oleh satu atau lebih pakar dalam bidang tertentu. Kombinasi dari kedua hal tersebut disimpan dalam komputer, yang selanjutnya digunakan dalam proses pengambilan keputusan untuk penyelesaian masalah tertentu. 


\subsection{Struktur Sistem Pakar}

Sistem pakar disusun oleh dua bagian utama, yaitu :
a. Lingkungan Pengembangan (Development Environtment)
b. Lingkungan Konsultasi (Consultation Environtment)

Lingkungan pengembangan sistem pakar digunakan untuk memasukkan pengetahuan pakar ke dalam lingkungan sistem pakar, sedangkan lingkungan konsultasi digunakan oleh pengguna yang bukan pakar guna memperoleh pengetahuan pakar.

\subsection{Basis Pengetahuan (Knowledge Base)}

Basis pengetahuan berisi pengetahuanpengetahuan dalam penyelesaian masalah, tentu saja di dalam domain tertentu. Ada dua bentuk pendekatan basis pengetahuan yang sangat umum digunakan diantaranya yaitu :

a. Penalaran berbasis aturan (Rule-Based Reasoning). Pada penalaran berbasis aturan,pengetahuan direpresentasikan dengan menggunakan aturan IF-THEN. Bentuk ini digunakan apabila telah memiliki sejumlah pengetahuan pakar pada suatu permasalahan tertentu dan si pakar dapat menyelesaikan masalah tersebut secara berurutan.

b. Penalaran berbasis kasus (Case-Based Reasoning). Pada penalaran berbasis kasus, basis pengetahuan akan berisi solusi-solusi yang telah dicapai sebelumnya, kemudian akan diturunkan suatu solusi untuk keadaan yang terjadi sekarang (fakta yang ada). Bentuk ini digunakan apabila user menginginkan untuk tahu lebih banyak lagi pada kasuskasus yang hampir sama.

\subsection{Motor Inferensi (Inferensi Engine)}

Mesin inferensi merupakan otak dari sistem pakar, bagian ini mengandung mekanisme fungsi berpikir dan pola-pola penalaran sistem yang digunakan oleh seorang pakar. Mekanisme ini akan menganalisa suatu masalah tertentu dan kemudian mencarikan jawaban atau kesimpulan yang terbaik. Dari fakta-fakta yang diperoleh selama proses tanya jawab dengan user, serta aturan-aturan yang tersimpan di knowledge base, inference engine dapat menarik suatu kesimpulan dan memberikan rekomendasi atau saran yang diharapkan oleh user.

Proses penalaran ada dua macam dan biasanya lebih disebut dengan proses chaining yaitu forward chaining dan backward chaining. Kedua metode ini mempunyai kelebihan tersendiri, semuanya itu tergantung dari kondisi permasalahan yang dihadapi dan basis pengetahuan.

\section{a. Forward Chaining}

Forward chaining merupakan suatu strategi pengambilan keputusan yang dimulai dari bagian sebelah kiri (IF terlebih dahulu). Dengan kata lain, penalaran dimulai dari fakta terlebih dahulu untuk menguji kebenaran hipotesis. Sebagai contoh penalaran maju (forward chaining) adalah mendiagnosa penyakit berdasarkan gejala-gejala atau fakta yang dirasakan oleh pasien.

\section{b. Backward Chaining}

Backward Chaining merupakan strategi pengambilan keputusan atau kesimpulan dengan pencocokan fakta atau pernyataan yang dimulai dari bagian sebelah kanan (THEN terlebih dahulu). Dengan kata lain, penalaran dimulai dari hipotesis terlebih dahulu, dan untuk menguji kebenaran hipotesis tersebut harus dicari fakta-fakta yang ada dalam basis pengetahuan.

\subsection{Diagnosa}

Menurut menurutparaahli.com Diagnosa atau Diagnosis adalah "identifikasi sifat-sifat penyakit atau kondisi atau membedakan satu penyakit atau kondisi dari yang lainnya. Penilaian dapat dilakukan melalui pemeriksaan fisik, tes laboratorium, atau sejenisnya, dan dapat dibantu oleh program komputer yang dirancang untuk memperbaiki proses pengambilan keputusan".

Menurut para ahli Thorndike dan Hagen dalam Suherman (2011), diagnosis dapat diartikan sebagai berikut:

a. Upaya atau proses menemukan kelemahan atau penyakit (weakness, disease) apa yang dialami seseorang dengan melalui pengujian dan studi yang seksama mengenai gejala-gejalanya (symptons).

b. Studi yang seksama terhadap fakta tentang suatu hal untuk menemukan karakteristik atau kesalahan-kesalahan dan sebagainya yang esensial.

c. Keputusan yang dicapai setelah dilakukan suatu studi yang seksama atas gejalagejala atau fakta tentang suatu hal.

Dari ketiga pengertian di atas, dapat disimpulkan bahwa di dalam konsep diagnosis, secara implisit telah tercakup pula konsep 
prognosisnya. Dengan demikian dalam proses diagnosis bukan hanya sekadar mengidentifikasi jenis dan karakteristiknya, serta latar belakang dari suatu kelemahan atau penyakit tertentu, melainkan juga mengimplikasikan suatu upaya untuk meramalkan kemungkinan dan menyarankan tindakan pemecahannya.

\subsection{Penyakit}

Ada beberapa pengertian penyakit menurut para ahli yaitu :

3.1 Menurut Dr. Beate Jacob, Penyakit merupakan "sebuah penyimpangan dari kondisi tubuh normal menuju ke ketidakharmonisan jiwa".

3.2 Menurut Thoma Timmreck, Penyakit dapat diartikan sebagai "sebuah keadaan dimana terdapat gangguan terhadap bentuk ataupun fungsi salah satu bagian tubuh yang menyebabkan tubuh menjadi tidak dapat bekerja dengan normal".

3.3 Menurut Elizabeth J. Crown, Penyakit merupakan Pperihal hadirnya sekumpulan respons tubuh yang tidak normal terhadap agen, yang mana manusia memiliki toleransi yang sangat terbatas atau bahkan tidak memiliki toleransi sama sekali".

\subsection{Unified Modelling Language (UML)}

Menurut Nugroho (2010) UML (Unified Modeling Language) adalah bahasa pemodelan untuk sistem atau perangkat lunak yang berparadigma (berorientasi objek). Pemodelan (modelling) sesungguhnya digunakan untuk penyederhanaan permasalahan-permasalahan yang kompleks sedemikian rupa sehingga lebih mudah dipelajari dan dipahami.

Menurut Yuni Sugiarti (2013) adalah "sebuah bahasa untuk menentukan, visualisasi, kontruksi, dan mendokumentasikan artifact (bagian dari informasi yang digunakan atau dihasilkan dalam suatu proses pembuatan perangkat lunak. Artifact dapat berupa model atau deskripsi perangkat lunak) dari sistem perangkat lunak", seperti pada pemodelan bisnis dan sistem non perangkat lunak lainnya. Diagram berbentuk grafik yang menunjukkan simbol elemen model yang disusun untuk mengilustrasikan bagian atau aspek tertentu dari sistem. Sebuah diagram merupakan bagian dari suatu view tertentu dan ketika digambarkan biasanya dialokasikan untuk view tertentu.

\subsection{Android}

Android adalah sebuah perangkat lunak open source yang bertumpuk yang mencakup sistem operasi, middleware, dan aplikasi kunci Android Standart Development Kid (SDK) menyediakan perlengkapan dan Application Programming Interface (API) yang diperlukan untuk mengembangkan aplikasi pada platform Android menggunakan bahasa pemrograman Java (Reto Meier, 2009).

\subsection{SQLite Database}

SQLite Database merupakan embedded database atau database yang sudah masuk dalam paket yang dapat digunakan pada Android. SQLite dapat dibangun di Android dan memiiki fitur relasional database. Untuk dapat menggunakan fitur ini pengembang aplikasi android cukup mendefinisiksan perintah SQL untuk meng-create atau mengupdate database. Selanjutnya sistem pada android akan memahami hal-hal yang berhubungan dengan database. SQLite database akan otomatis tersimpan di dalam path data/data/nama_package/database/ nama database.

SQLite Database merupakan database lokal yang dapat digunakan untuk menyimpan data aplikasi dengan menggunkaan pendekatan terstuktur. Untuk pengecekaan database dapat diakses melalu IP address yang terdapat pada project android pada saat aplikasi di debug.

\section{Metodologi}

Metode bisa diartikan sebuah langkah yang tersusun secara sistematis yang bertujuan agar tercapainya sebuah tujuan dari dilakukannya sebuah penelitian.

\subsection{Metode Pengumpulan Data}

1. Studi Pustaka

Untuk mendukung perancangan aplikasi ini penulis menggunakan metode pustaka sebagai referensi. Pustaka yang digunakan antara lain : buku-buku referensi, jurnal, internet, atau penelitian sebelumnya yang berkaitan dengan AndroidObservasi

2. Interview

Melakukan interview dengan pihak terkait dan mengajukan pertanyaan lisan sehingga fakta atau data dapat diperoleh secara langsung dan tepat yang berhubungan dengan objek

\subsection{Metode Pengembangan Sistem}

Metode yang digunakan penulis dalam penelitian ini yaitu metode waterfall atau sering juga disebut model air terjun, pemilihan model waterfall dikarenakan model ini menyediakan pendekatan alur hidup 
perangkat lunak secara sekuensial atau terurut dimulai dari analasis, desain, pengodean, dan pengujian

\subsection{Metode Forward Chaining}

Forward chaining merupakan salah satu cara pemrograman yang menggunakan perintah "IF". Dengan kata lain, pemrograman ini menggunakan penalaran yang dimulai dari fakta terlebih dahulu untuk menguji kebenaran hipotesis. Muhammad Arhami mengungkapkan "Pelacakan ke depanadalah pendekatan yang dimotori data (data-driven). Dalam pendekatan ini pelacakan dimulai dari informasi masukan, dan selanjutnya mencoba menggambarkan kesimpulan". Pelacakan ke depan mencari fakta yang sesuai dengan bagian IF dari aturan IF-THEN.

Dalam penelitian ini basis pengetahuan direpresentasikan dengan menggunakan kaidah produksi, yaitu berupa IF - THEN. IF Kondisi1 (AND Kondisi2 ...) THEN Kesimpulan. Kaidah produksi merupakan statemen dua bagian yang disatukan menjadi sepenggal kecil pengetahuan. Kaidah bagian pertama IF yang menyatakan premis, kondisi atau antecedent, dan kaidah bagian kedua THEN yang menyatakan suatu kesimpulan atau konklusi. Pada contoh berikut diberikan beberapa inputan antecedent (mendahului) dan memberikan satu kesimpulan berdasarkan premis yang ada untuk menentukan jenis atau nama penyakit yang diderita pada manusia.

IF Demam

AND Kencing sedikit-sedikit sakit

AND Nyeri di akhir kencing

AND Kencing warna merah

\section{Kencing)}

THEN penyakit Infeksi Saluran Kemih (Sakit

(Demam, Kencing sedikit-sedikit sakit, Nyeri di akhir kencing, dan Kencing warna merah) benar, maka mesin inferensi mengambil kesimpulan bahwa pasien menderita penyakit Infeksi Saluran Kemih (Sakit Kencing).

\section{Perancangan Aplikasi}

\subsection{Analisa sistem yang berjalan}

Proses pemeriksaan pasien yang dilakukan pada Klinik Citra Raya Medika diantaranya, yaitu :

a. Dokter menanyakan keluhan apa yang dirasakan terhadap pasien.

b. Setelah menerima keluhan dari pasien, tindakan dokter selanjutnya adalah memeriksa pasien.

c. Dokter mendiagnosa berdasarkan hasil pemeriksaan dan gejala-gejala yang dirasakan oleh pasien. d. Dokter memberikan keputusan dengan menganalisis beberapa kemungkinan penyakit yang bisa diderita oleh pasien.

e. Dokter akan memberitahu apa saja yang harus dipantang jika pasien mengalami penyakit yang diderita.

f. Selain itu dokter akan memberikan resep obat atau solusi dari penyakit yang diderita pasien.

Perancangan sistem dilakukan untuk memberikan gambaran tentang sistem yang baru kepada user yaitu sistem berbasis Android.

Adapun proses perancangan sistem yang baru yang akan digunakan oleh user yaitu sebagai berikut :

a. User membuka aplikasi sistem pakar penyakit umum.

b. Di menu utama terdapat tiga pilihan menu button yaitu Diagnosa, Informasi Penyakit, dan Tentang.

c. Untuk mengetahui diagnosa penyakit, maka user terlebih dahulu memilih gejalagejala yang dialami dengan memilih menu button Diagnosa.

d. Pada menu button informasi penyakit, ada beberapa penjelasan definisi terhadap penyakit tersebut.

e. Pada menu button Tentang, hanya berisi tentang penjelasan terhadap aplikasi yang dibuat. 


\subsection{Modelling sistem yang diusulkan}

\section{Use Case Diagram}

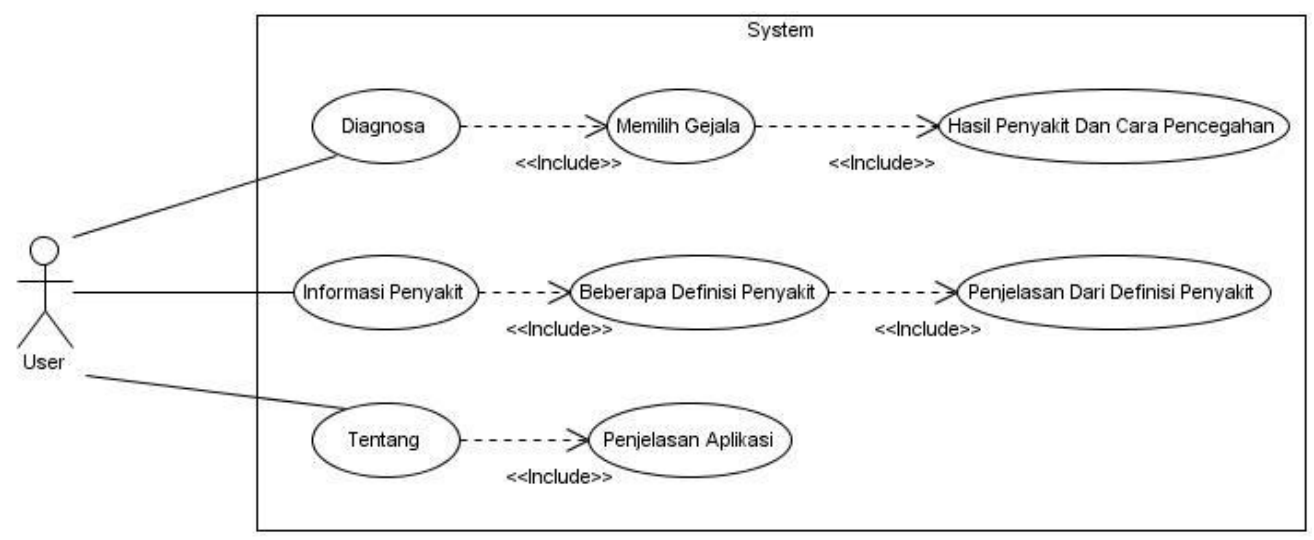

Gambar 4.1 Use case aplikasi sistem pakar

\section{Activity Diagram}

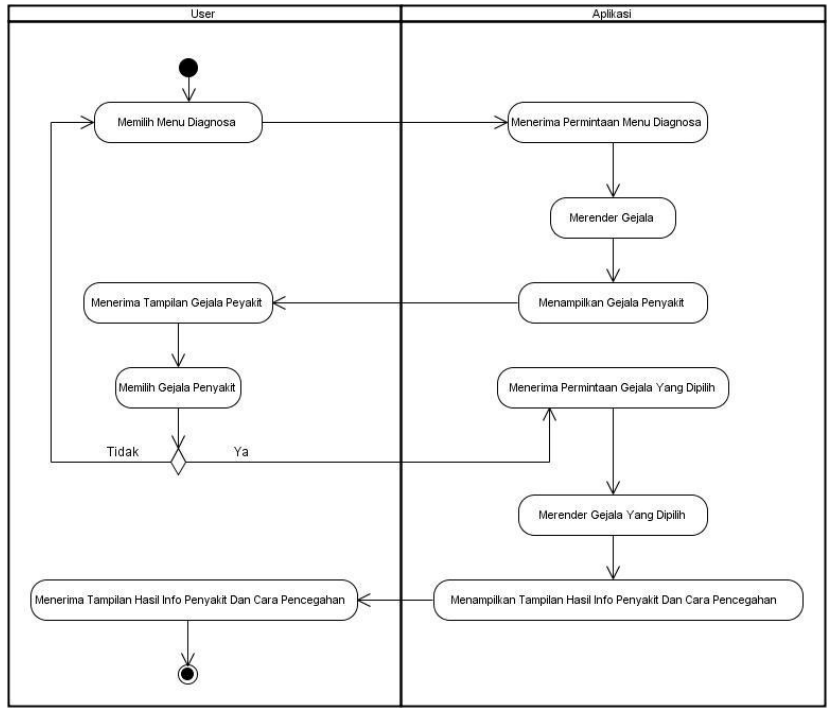

Gambar 4.2 Activity diagnosa

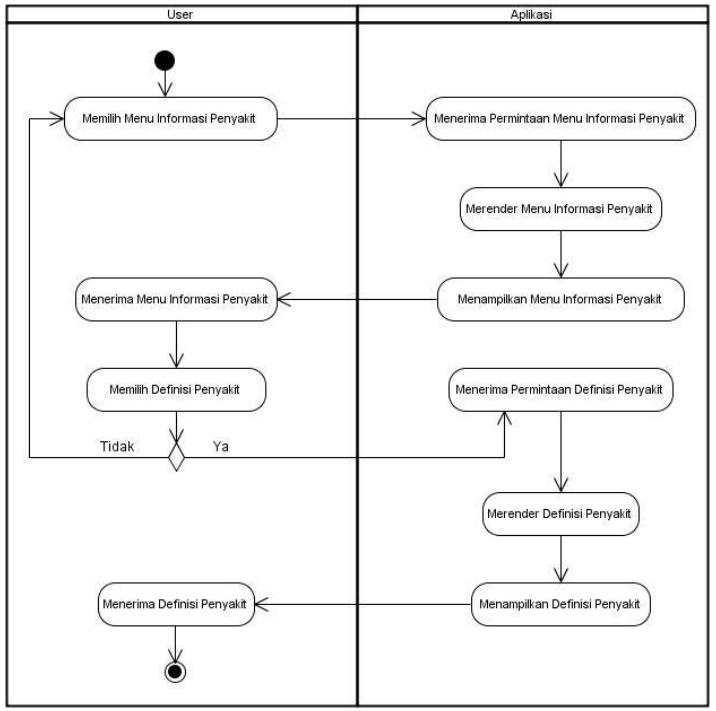

Gambar 4.5 Activity penyakit

\section{Class diagram}

\begin{tabular}{|c|c|c|}
\hline Gejala & Penyakit & Pencegahan \\
\hline $\begin{array}{l}\text {-id_gejala : int } \\
\text {-kd_gejala : text } \\
\text {-nm_gejala : text }\end{array}$ & \multirow{2}{*}{$\begin{array}{l}\text {-id_penyakit : int } \\
\text {-kd_penyakit : text } \\
\text {-nm_penyakit : text } \\
\text {-kd_gejala : text }\end{array}$} & \multirow{2}{*}{$\begin{array}{l}\text {-id_pencegahan : int } \\
\text {-kd_pencegahan : text } \\
\text {-nm_pencegahan : text } \\
\text {-kd_gejala : text }\end{array}$} \\
\hline +tambah() & & \\
\hline $\begin{array}{l}\text { +edit() } \\
\text { +hapus() }\end{array}$ & $\begin{array}{l}\text { +tambah() } \\
\text { +edit() } \\
\text { +hapus() }\end{array}$ & $\begin{array}{l}\text { +tambah() } \\
\text { +edit() } \\
\text { +hapus() }\end{array}$ \\
\hline
\end{tabular}

Gambar 4.6 Class diagram sistem pakar penyakit 


\subsection{Implementasi}

\section{Menu Utama}

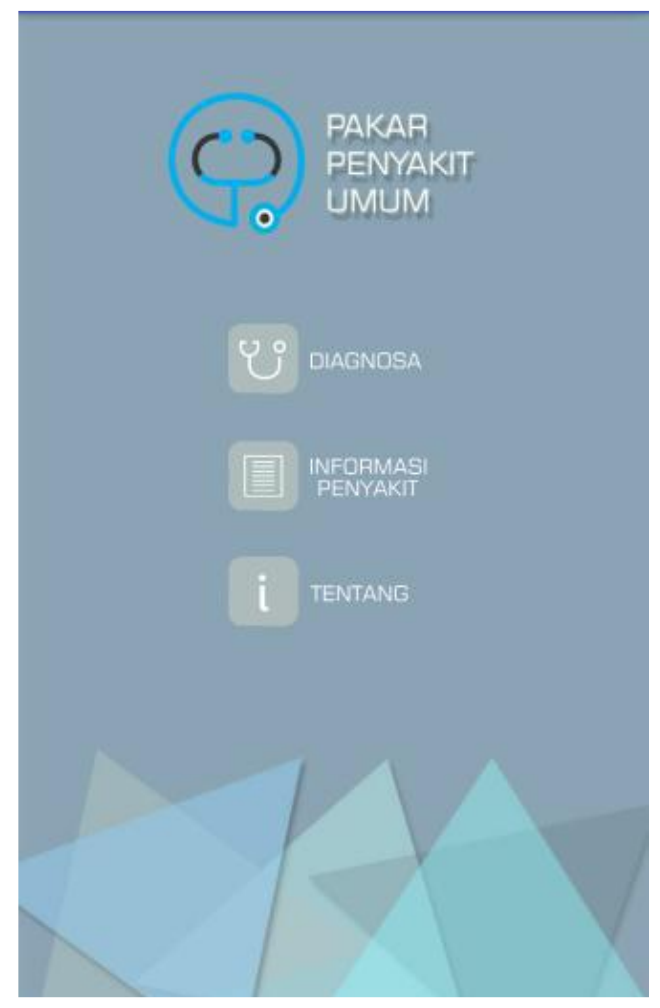

Gambar 4.7 UI Menu Utama

\section{Hasil Diagnosa}

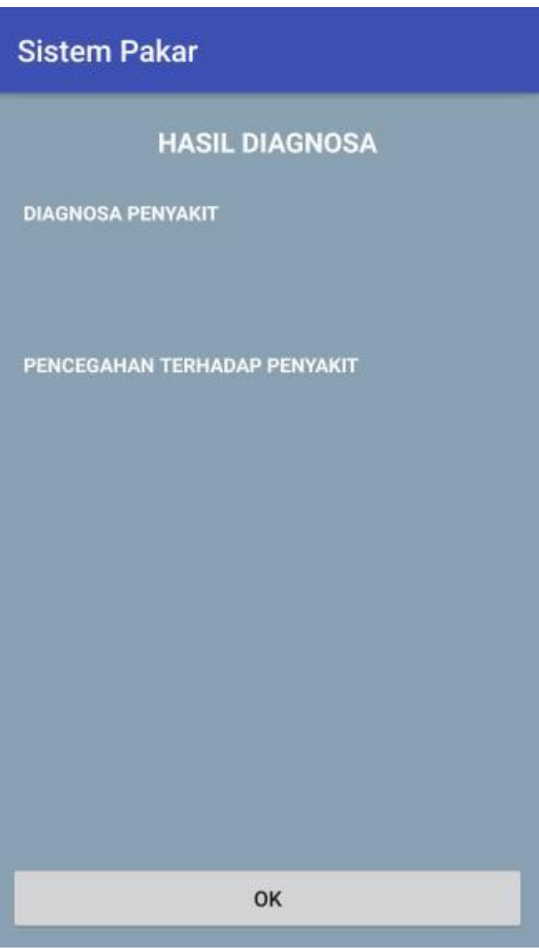

Gambar 4.9 UI Hasil diagnosa

\section{Diagnosa}

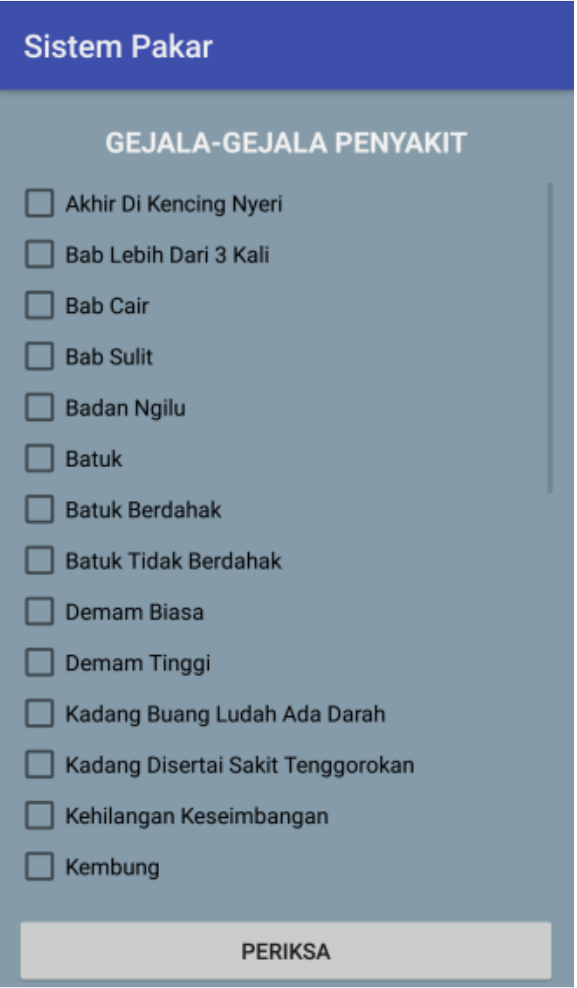

Gambar 4.8 UI Diagnosa

\section{Pilihan Informasi Penyakit}

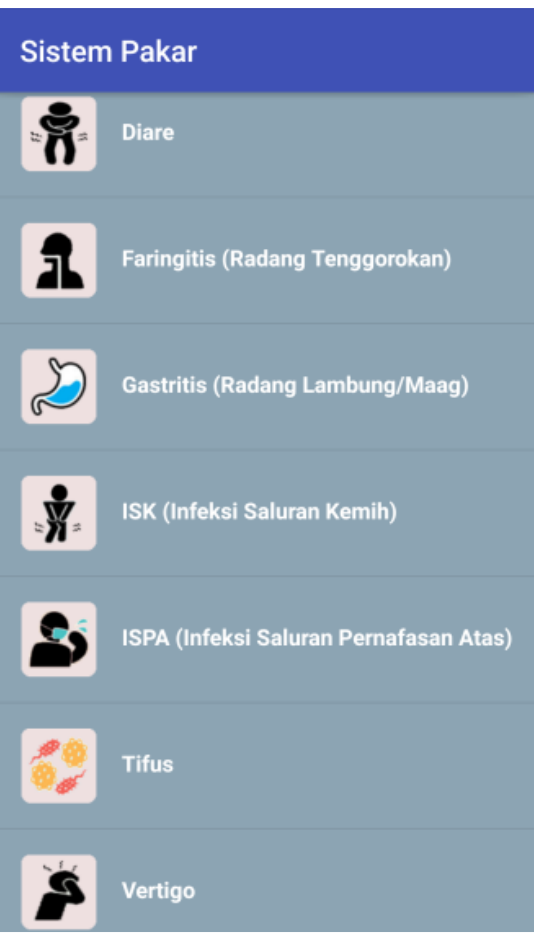

Gambar $4.10 \mathrm{UI}$ Informasi penyakit 


\section{Informasi Penyakit}

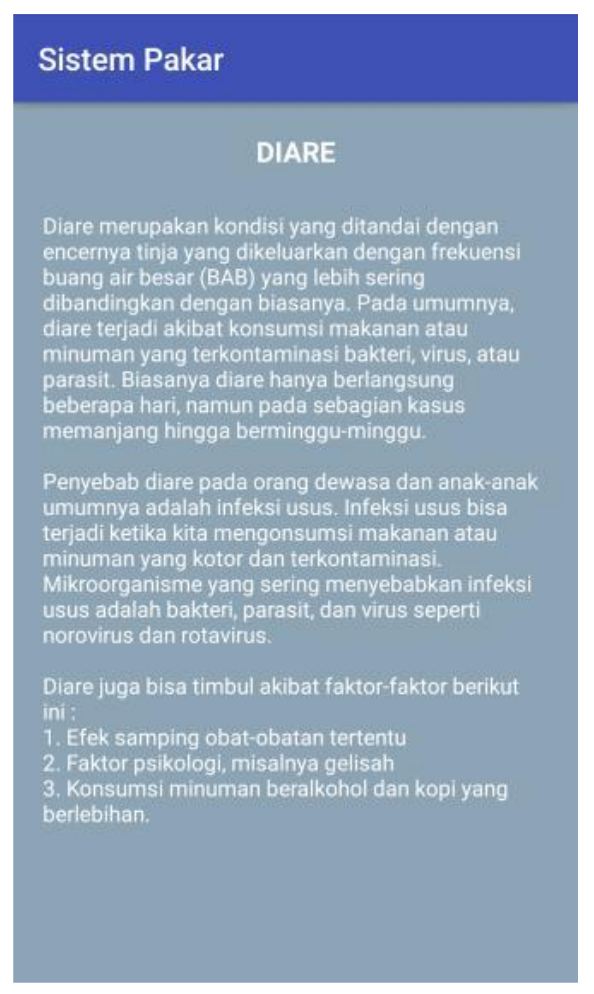

Gambar 4.11 UI Informasi penyakit

\section{Kesimpulan dan Saran}

\subsection{Kesimpulan}

Kesimpulan Berdasarkan hasil uraian di atas, maka dapat disimpulkan.

1. Aplikasi sistem pakar diagnosa penyakit umum ini meliputi proses diagnosa awal terhadap suatu gejala penyakit serta memberitahu hasil nama penyakit serta cara pencegahan terhadap penyakit tersebut.

2. Aplikasi sistem pakar penyakit umum ini dapat membantu masyarakat untuk memilih gejala-gejala yang dirasakan serta menghasilkan penyakit yang dialami oleh manusia dan juga cara pencegahan terhadap penyakit tersebut. Sistem pakar penyakit umum ini juga dipakai oleh user melalui handphone berbasis sistem operasi Android, sehingga memudahkan dan meringankan pasien.

3. Aplikasi ini hanya untuk penanganan awal dan bukan untuk menggantikan posisi dokter

4. Aplikasi ini bersifat edukatif bukan solutif

\subsection{Saran}

Adapun saran-saran penulis untuk pengembangan selanjutnya dan penerapan sistem yang di usulkan antara lain :

1. Mengingat besarnya pengetahuan penyakit umum pada manusia, maka

\section{Menu Exit}

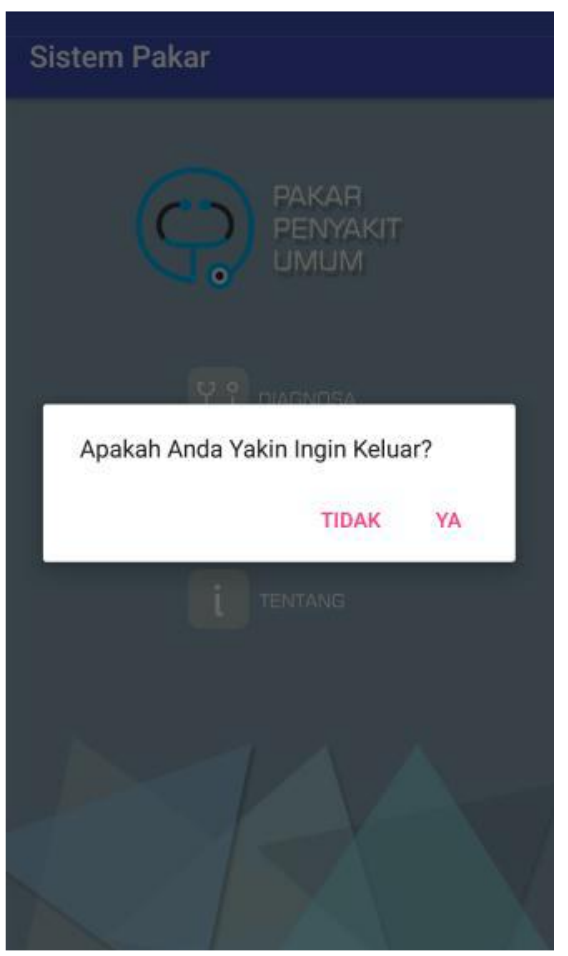

Gambar 4.12 Menu Exit

ruang lingkup sistem dalam melakukan diagnosa suatu penyakit dapat dikembangkan menjadi lebih luas dan lebih kompleks terutama penambahan faktor-faktor lain selain gejala penyakit, seperti usia dan jenis kelamin yang dapat menunjang diagnosis penyakit. Menambah jenis-jenis penyakit yang dapat didiagnosis, agar sistem semakin akurat dalam melakukan diagnosis penyakit.

2. Sistem pakar ini juga dapat dikembangkan lebih lanjut agar tampilan aplikasi menjadi lebih menarik, dengan ditambahkan gambar, suara serta animasi.

\section{Daftar pustaka}

[1] Crown J. Elizabeth, 2009, Buku Saku Patofisiologi, EGC, Jakarta

[2] Husda, Nur Elfi, Yvone Wangdra, 2016, Pengantar Teknologi Informasi, Baduose Media, Jakarta

[3] Jacob, Beate, 1982, Specialis of psychology, pargament, New York 
[4] Nugroho, Adi, 2010, Rekayasa Perangkat Lunak berbasis Obyek dengan metode USDP, Andi Offset, Yogyakarta

[5] Pressman, R.S, 2010, Software Engineering : a practitioner's approach, McGraw-Hill, New York

[6] Reto Meier, 2009, Profesional Android Application Development, Wiley publishing, Canada

[7] Thorndike, R.L., and Hagen E,E.,2011, Measurement and Evaluation in Psychology and Education. New York

[8] Thomas C, Timmreck, 2005, Epidemiologi Suatu Pengantar, EGC, Jakarta

[9] Yuni, Sugiarti, 2013, Analisis dan Perancangan UML (Unified Modelling Language) General VB.6, Graha Ilmu, Yogyakarta 